\title{
Efficacy of Butanolic Fraction of Cocos Nucifera's Root Aqueous Extract on Induced Anemia Treatment
}

\author{
Tchogou $\mathrm{AP}^{1,2}$, Sènou $\mathrm{M}^{1,2}$, Agbogba $\mathrm{F}^{1,3}$, Lokonon $\mathrm{JE}^{1}$, Medoatinsa $\mathrm{SE}^{1}$, Agbangnan Dossa $\mathrm{CP}^{4}$, Loko $\mathrm{F}^{2}$, Agbonon $\mathrm{A}^{5}$ \& \\ Sèzan $\mathrm{A}^{3}$ \\ ${ }^{1}$ Experimental and Clinic Biology Laboratory, National School of Applied Biosciences and Biotechnologies, National \\ University of Science, Technology, Engineering and Mathematics (UNSTIM), Dassa-Zoumé, R. Benin \\ 2 Research Laboratory in Applied Biology, Polytechnic School of Abomey-Calavi, University of Abomey-Calavi, \\ Cotonou, R. Benin \\ ${ }^{3}$ Laboratory of Biomembrane and Cell Signaling, Faculty of Sciences and Techniques, University of Abomey-Calavi, R \\ Benin \\ ${ }^{4}$ Laboratory of Study and Research in Applied Chemistry, Polytechnic School of Abomey-Calavi, University of \\ Abomey-Calavi, R. Benin \\ ${ }^{5}$ Laboratoire de Physiologie/Pharmacologie, Faculté des Sciences, Université de Lomé, R. Togo \\ Correspondence: Medoatinsa SE, Experimental and Clinic Biology Laboratory, National School of Applied Biosciences \\ and Biotechnologies, National University of Science, Technology, Engineering and Mathematics (UNSTIM), \\ Dassa-Zoumé, R. Benin.
}

Received: September 1, 2021

Accepted: October 9, $2021 \quad$ Online Published: November 11, 2021

doi:10.5539/ijb.v13n2p49

URL: https://doi.org/10.5539/ijb.v13n2p49

\begin{abstract}
Cocos nucifera was a coastal plant whose roots were used in pharmacopoeia to treat anemia in Benin. The aqueous extract from its roots stimulated the synthesis of hemoglobin. The aim of this work was to test in vivo the efficacy of the butanolic fraction of the extract in the treatment of anemia. Methods: Wistar rats were anemic with phenylhydrazine for two days. From D2 to D15, some were treated by gavage with the butanolic fraction of the aqueous extract of Cocos nucifera roots at the dose of $40 \mathrm{mg}$ or $60 \mathrm{mg} / \mathrm{kg}$ of body weight / day, others were treated with vitafer (an anti-anemic drug) or with distilled water. The rats blood were collected on days D0, D2, D7, D10 and D15 for the complete blood count and the osmotic resistance of the red blood cells. Results: On D2, phenylhydrazine significantly lowered the hemoglobin level and the number of red blood cells, which were respectively corrected on D10 and D15 by the fraction of extract with release of hypochromic macrocytes. However, the effect was slower than that of the crude extract, was not specific to erythropoiesis because it also stimulated thrombopoiesis and was not dose-dependent. Conclusion: The butanolic fraction of the aqueous extract of Cocos nucifera roots corrected anemia by stimulation of hematopoiesis. The observed biological activity would probably be linked to anthocyanins which are mainly isolated by butanol. These results contribute to a better knowledge of bioactive compounds of our antianemic plants.
\end{abstract}

Keywords: Cocos nucifera, roots, butanol, hematopoiesis

\section{Introduction}

Anemia is a major public health problem around the world (de Benoist et al., 2008). It affects populations of all ages but mostly pregnant women and children. Anemia is defined as a low level of circulating hemoglobin with a value of less than $11 \mathrm{~g} / \mathrm{dl}$ in children. (UNICEF, 2017).

In Africa, the causes of anemia are multiple. They are often linked to parasitic diseases such as malaria, bacterial infections and various nutritional deficiencies (UNICEF, 2015). Iron deficiency is the first cause of carentiel anemia. It affects about $30 \%$ of the world's population (Staubli Asobayire, 2005). Iron is an important component of hemoglobin, a pigment in the red blood cell that carries oxygen (Upasana, 2018).

In developing countries, $80 \%$ of the population in rural areas use medicinal plants to solve various health problems (Sofowora, 1996). The main reason being the inaccessibility and high cost of pharmaceutical drugs (Gbéassor, 1989). In Africa, the majority of people with anemia are treated with infusions, decoctions of the leaves, bark or roots of medicinal plants a combination of these (Akah et al., 2009). Among these plants, we can mention Manihot esculenta, Plastotoma 
africanum, Ricinodendron heudelotii, Sacoglottis gabonensis and Cocos nucifera (Agbor et al., 2005; Sènou et al., 2016a; Tchogou et al., 2016 and Bayengue et al., 2017).

Cocos nucifera (L.) is an important member of the family Arecaceae (palm family) popularly known as coconut is a plant from the coastal regions. Studies have shown that the aqueous extract of its roots effectively treats anemia as well as its ethyl acetate fraction (Tchogou et al., 2016, Sènou et al., 2017). The phytochemical screening of the extract which revealed anthocyanins (Tchogou et al., 2017), the objective of this work is to test the butanolic fraction of the extract which isolates them mainly (Manjusha et al., 2013 ; Koudoro et al., 2014) in order to to see if it has hematopoietic activity.

\section{Material and Methods}

\subsection{Animal Material}

These are Wistar rats with an average body weight of approximately $150 \mathrm{~g}$. They are acclimatized to the conditions of the animal house of the Applied Biology Research Laboratory of the Polytechnic of Abomey-Calavi of the University of Abomey-Calavi in Benin. Breeding was done in a well-ventilated room, with a day-night rhythm of $12 \mathrm{~h}$. The animals were kept in wire mesh cages with metal feeders and drinking troughs. Their daily diet was made from a mixture of food in the form of croquettes and marketed by Vet Services (Benin). The enclosure was regularly cleaned to ensure optimal development of the animals avoid infection. All the rules for animal welfare have been observed.

\subsection{Preparation of Plant Material}

Identification: The roots of Cocos nucifera were harvested in Abomey-Calavi in Benin in April 2015 and were identified at the National Herbarium of Benin (HNB) at the University of Abomey-Calavi. The samples were dried at moderate temperatures $\left(20-25^{\circ} \mathrm{C}\right)$, protected from moisture for four weeks. They were then crushed powder and stored in suitable containers at room temperature.

Cocos nucifera root extract preparation: $50 \mathrm{~g}$ of root powder of Cocos nucifera were boiled in $500 \mathrm{ml}$ of distilled water in a $1000 \mathrm{ml}$ flask for 30 minutes. After cooling, the mixture is filtered using the Bushner. This operation is repeated for six times for a total mass of $300 \mathrm{~g}$. The filtrate (the aqueous phase) obtained is recovered and stored in a refrigerator in a jar for liquid-liquid extraction (first fractionation step).

Extract fractionation: Liquid-liquid extraction consists in passing a substance from a solvent, from which it is often difficult to separate, to another (called extraction solvent), from which it will be easily isolable. This operation, usually carried out by stirring, is possible provided that the two solvents are very little or no miscible with one another. But extraction is never $100 \%$, there are always molecules of the compound to be extracted in the solvent in which it is less soluble.

The Liquid-liquid was obtained by successive partitions with solvents of increasing polarity (hexane and butanol) according to the protocol of Koudoro et al. (2014). In a separatory funnel, was added to the aqueous extract solution the appropriate volume of extraction solvent. After vigorous agitation, the mixture was allowed to settle. After decantation, the two phases were separated by collecting the lower phase (aqueous phase) in a flask and the upper phase (organic phase) in another. The aqueous phase was re-poured into the separating funnel before repeating the following steps. After each extraction step, the organic phases were combined, which constituted the fraction in a jar. The liquid-liquid extracts obtained was then evaporated using a rotary evaporator at a temperature according to the solvents of polarity. The extractant phase was re-sealed and solidified in an oven at $40^{\circ} \mathrm{C}$. The dry residue obtained was reduced to powder and stored in a refrigerator in a brown flask.

\subsection{In Vivo Experimentation}

Describe the procedures for selecting participants, including (a) the sampling method, if a systematic sampling To assess the antianemic activity of the butanolic fraction of the aqueous extract of Cocos nucifera roots, complete blood count and osmotic resistance of red blood cells were determined in anemic Wistar rats.

Anemia induction: Phenylhydrazine chloridrate was dissolved in DMSO previously diluted to tenths in distilled water. It was then injected into rats intraperitoneally at $40 \mathrm{mg} / \mathrm{kg}$ of body weight for two days (D0 and D1).

Protocol: Five groups of five rats each were formed. Group 1 was not anemic and served as control. The rats of other groups were all anemic. Group 2 rats were not treated and receved only distilled water. Group 3 rats were treated with vitafer. The tow last groups receved $40 \mathrm{mg}$ extract fraction / $\mathrm{kg}$ of body weight / day (group 3) or $60 \mathrm{mg}$ extract fraction / kg of body weight / day (group 4) from D2 to D15. The extract and vitafer were administered by gavage using a gastric tube. Vitafer is reference drug commonly used to treat anemia. The rats were treated from D2 to D15.

Blood tests: $2 \mathrm{ml}$ of blood samples were collected in EDTA tube on days: D0, D2, D7, D10 and D15 for the determination of the blood count and osmotic resistance of red blood cells. Anesthesia of the rats was performed with chloroform. 


\subsubsection{Blood Count}

Hematological parameters such as hemoglobin, the number of red blood cells, mean corpuscular volume and mean corpuscular hemoglobin concentration number of platelets were determined with PLC SYSTEM KX 21 (Ganong, 2001).

\subsubsection{Osmotic Resistance of Erythrocytes}

The test was based on the ability of red cells to resist to hemolysis in a hypotonic solution. Blood was diluted 1/200 in two salt solutions of different concentrations. One was isotonic $(0.9 \% \mathrm{NaCl})$ and the other hypotonic $(0.45 \% \mathrm{NaCl})$. Red cells were counted with a Malassez cell. The ratio of the number of red blood cells counted in the hypotonic solution over that of the isotonic solution was the percentage of red blood cells resistant to hemolysis. This test was use to assess the production of young red blood cells.

\subsection{Statistical Analysis}

Graphs were plotted using Graph pad software. Results were expressed as the mean $\pm 2 x$ standard error on the mean. In each group, the different means were compared to that of D0 using ANOVA one way, Dunnett's Multiple Comparison Test. The significance level was set at $5 \%$.

\section{Results}

\subsection{Evolution of Hemoglobin Level}

On D0, the hemoglobin level ranged from $13.9 \pm 0.3$ to $15.1 \pm 1.0 \mathrm{~g} / \mathrm{dl}$ in the various groups of rats. It dropped on D2 following administration of phenylhydrazine and ranged from $8.1 \pm 0.5$ to $9.6 \pm 0.7 \mathrm{~g} / \mathrm{dl}$ in the anemic groups. This drop in hemoglobin level was corrected from D10 in groups treated with vitafer or the butanolic fraction of Cocos nucifera root extract at 40 or $60 \mathrm{mg}$ per $\mathrm{kg}$ of body weight.

In the anemic untreated group, the increase in hemoglobin level was slower and did not reach its D0 value at D15.

In the non-anemic control group, the hemoglobin level did not change during the experimental period (figure 1).

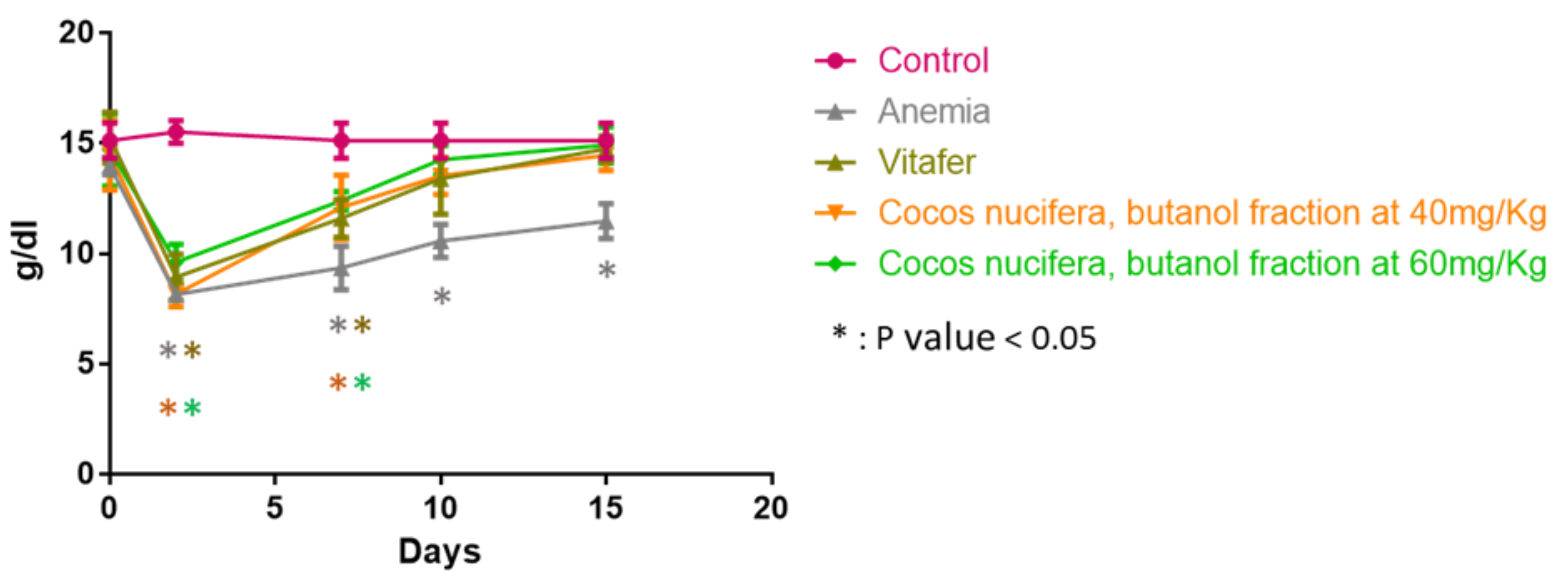

Figure 1. Effect of treatment on hemoglobin level in various groups of rats

\subsection{Evolution of the Number of Red Blood Cells}

On D0, the number of red blood cells varied from $6.7 \pm 0.3$ to $7.8 \pm 0.6 \mathrm{~T} / 1$ in the various groups of rats. It drops on D2 following hemolysis induced by phenylhydrazine and ranged from $2.9 \pm 0.2$ to $3.5 \pm 0.3 \mathrm{~T} / \mathrm{l}$ in the anemic groups. This drop in the number of red blood cells was corrected from D10 in group treated with vitafer and from D15 in those treated with the butanolic fraction of Cocos nucifera root extract at 40 or $60 \mathrm{mg}$ per $\mathrm{kg}$ of body weight.

In the anemic untreated group, the increase in red blood cells number was slower and did not reach its D0 value at D15. In the non-anemic control group, the number of red blood cells did not change during the experimental period (figure 2). 


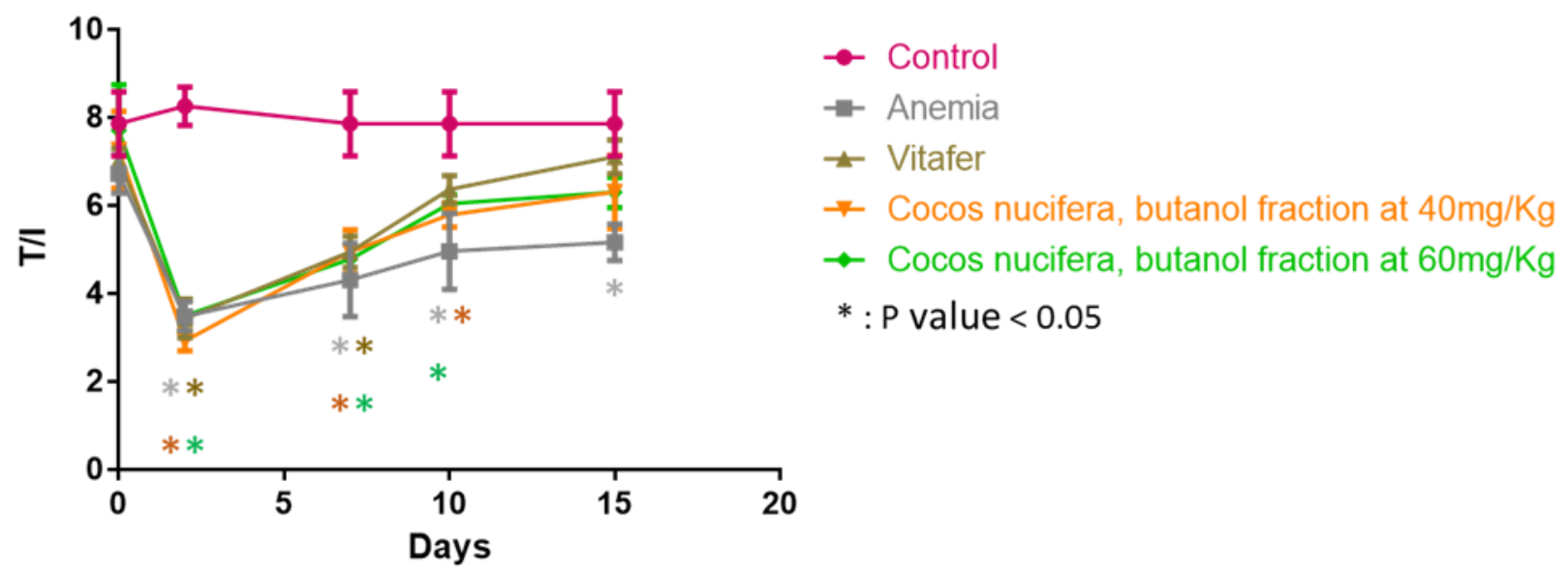

Figure 2. Effect of treatment on the number of red blood cells in the various groups of rats

\subsection{Evolution of the Mean Corpuscular Volume}

The mean red blood cell volume ranged from $58 \pm 2$ to $62 \pm 1 \mathrm{fl}$ on D0. It gradually increased in the anemic groups and reached a peak on D7 with values between $77 \pm 2$ and $92 \pm 10 \mathrm{fl}$ corresponding to a release of macrocytes in the blood.

In the non-anemic control group, the mean corpuscular volume did not change during the experimental period (figure 3).

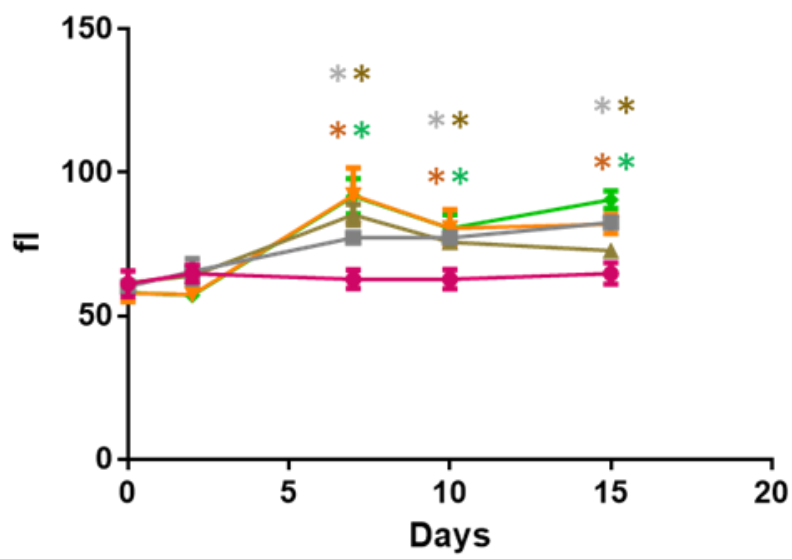

$\rightarrow$ Control

$\rightarrow$ Anemia

$\mp$ Vitafer

* Cocos nucifera, butanol fraction at $40 \mathrm{mg} / \mathrm{Kg}$

$\rightarrow$ Cocos nucifera, butanol fraction at $60 \mathrm{mg} / \mathrm{Kg}$

* : P value $<0.05$

Figure 3. Effect of treatment on blood cell volume in various groups of rats

\subsection{Evolution of the Mean Corpuscular Hemoglobin Concentration}

The mean corpuscular hemoglobin concentration varied from $33 \pm 1$ to $35 \pm 1 \mathrm{~g} / \mathrm{dl}$ on D0. It had significantly increased on D2 in the anemic groups with values of $38 \pm 2$ to $41 \pm 1 \mathrm{~g} / \mathrm{dl}$ corresponding to the presence of red blood cells saturated with hemoglobin in the blood. It then rapidly decrease with a peak at D7 in the anemic untreated group and in the anemic treated groups with the extract fraction, corresponding to a release of red blood cells that are little saturated with hemoglobin. The mean corpuscular hemoglobin concentration was no longer significantly different compared to D0 from D10 in the group treated with $60 \mathrm{mg}$ extract fraction/ $\mathrm{Kg}$ and from D15 in that treated with $40 \mathrm{mg}$ extract fraction / Kg of body weight, which reflects a release of mature red blood cells in the blood.

In the group treated with vitafer, the mean corpuscular hemoglobin concentration was not significantly different from D0 at D7.

In the non-anemic control group, the mean corpuscular hemoglobin concentration did not change during the experimental period (figure 4). 


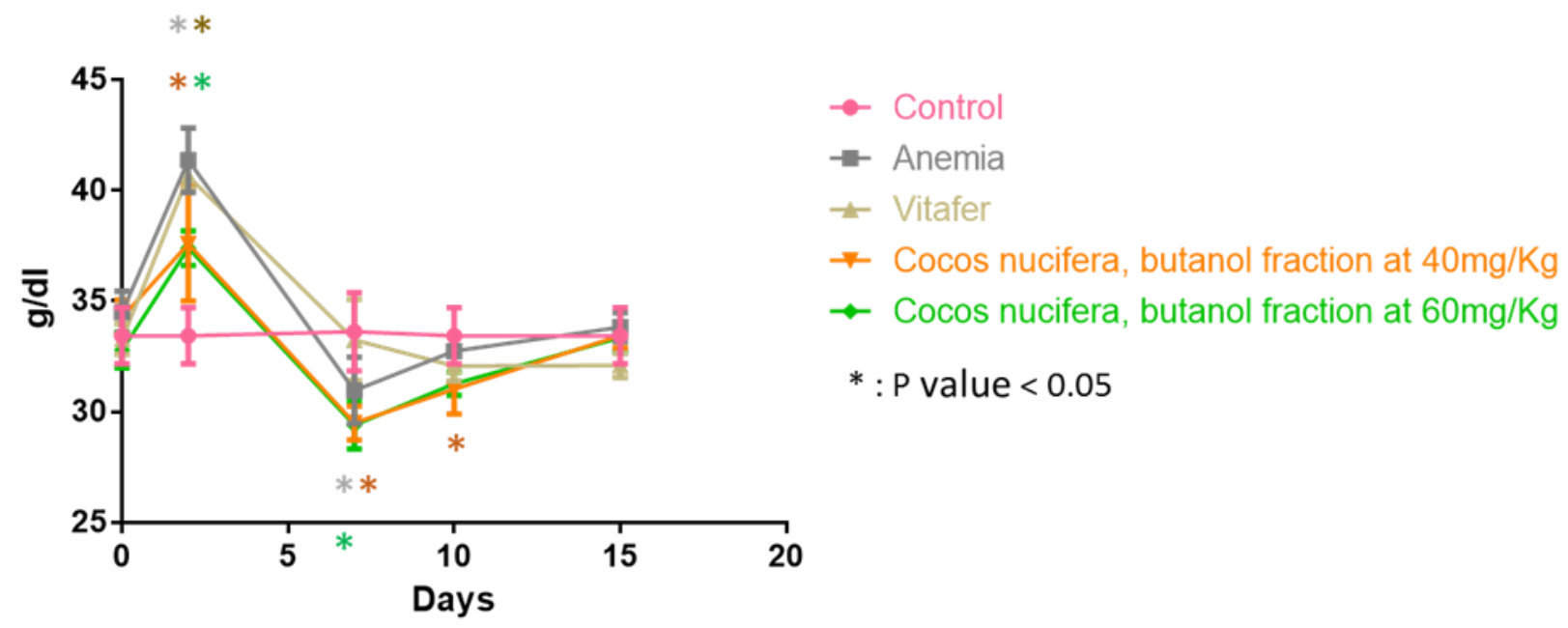

Figure 4. Effect of treatment on corpuscular hemoglobin concentration in various groups of rats

\subsection{Evolution of Osmotic Resistance of Red Blood Cells}

The osmotic resistance of the red blood cells varied from $18 \pm 7 \%$ to $22 \pm 8 \%$ at D0 in the different groups of rats. It had significantly increased from D2 to reach a peak at D7 in all anemic groups with values from $60 \pm 9 \%$ to $71 \pm 5 \%$, reflecting a release of young red blood cells into the bloodstream. At D15, the osmotic resistance is no longer significantly different from D0 in the group treated with vitafer.

In the non-anemic control group, the red blood cells osmotic resistance did not significatly change during the experimental period (figure 5).
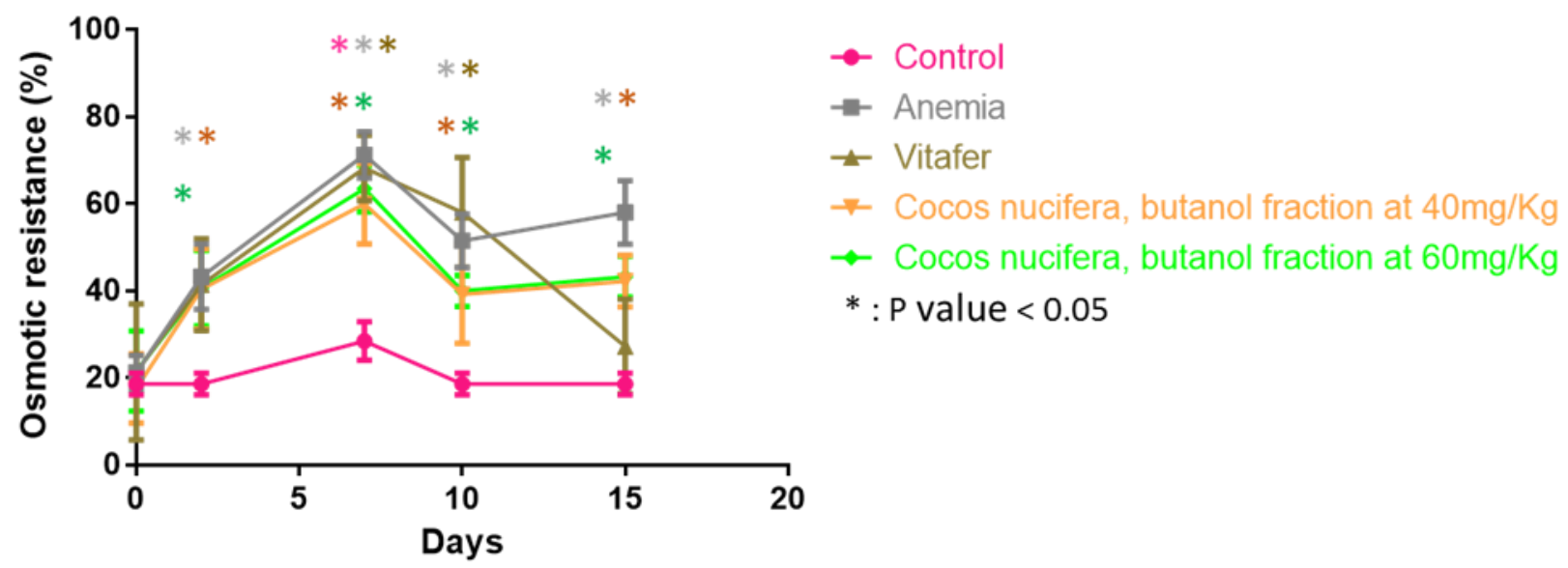

Figure 5. Effect of treatment on osmotic resistance of red blood cells in various groups of rats

\subsection{Evolution of the Number of Blood Platelets}

The number of blood platelets ranged from $345 \pm 120$ to $502 \pm 80 \mathrm{G} / 1$ in the various groups of rats on D0. It increased significantly with a peak on D2 in all the anemic and non-anemic groups. It then gradually decreased and is no longer significantly different from its initial value in all the groups except that treated with $60 \mathrm{mg}$ of extract fraction / Kg of body weight, suggesting a thrombopoietic activity of the extract fraction at this dose (figure 6). 


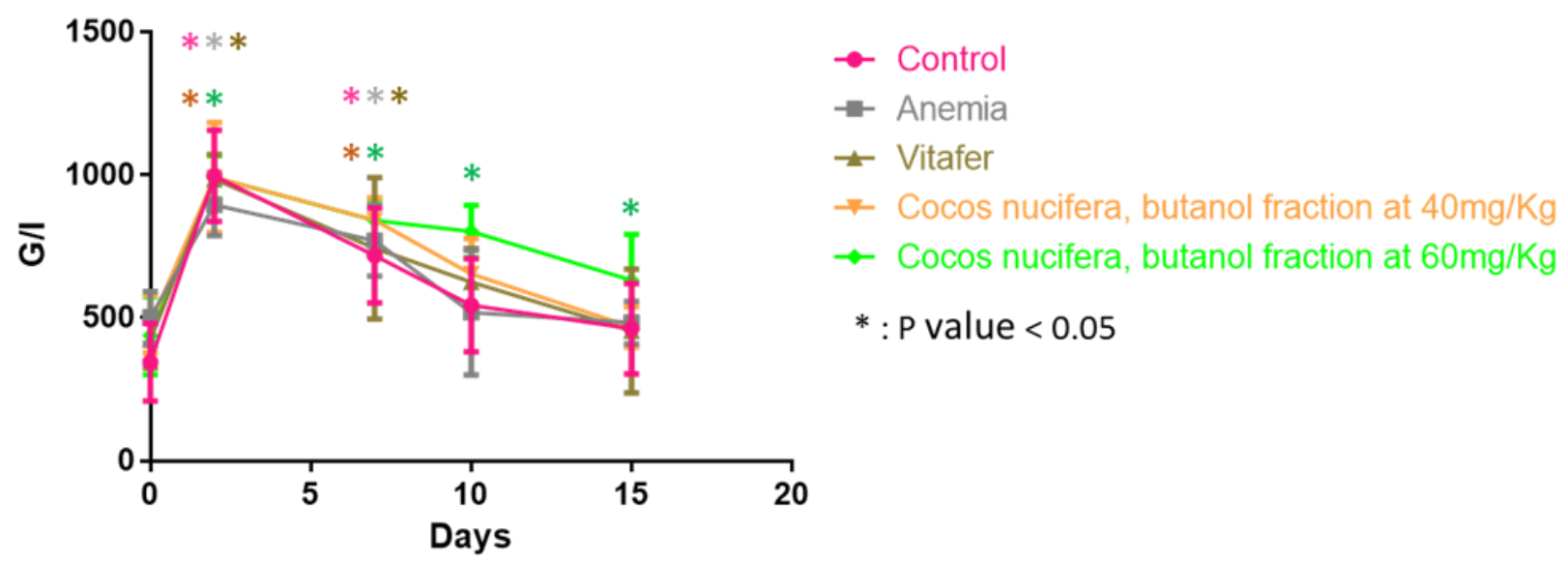

Figure 6. Treatment effect on the number of blood platelets in various groups of rats

\section{Discussion}

The roots of Cocos nucifera were used in traditional medicine to treat anemia and scientific studies have proven its therapeutic efficacy (Tchogou et al., 2016). To explore the mechanism of action of the extract, a phytochemical screening was performed and revealed including the presence of anthocyanins (Tchogou et al., 2017). In order to test the hematopoietic activity of anthocyanins, the extract of the roots of Cocos nucifera was fractionated with butanol which mostly isolated them (Manjusha et al., 2013; Koudoro et al., 2014). In this work, this extract fraction was administered to anemic Wistar rats for two weeks and its effect on the blood count and osmotic resistance of red blood cells was measured.

The key parameter indicating anemia was hemoglobin level. The decrease in hemoglobin level induced on D2 by phenylhydrazine was corrected on D10 in the groups treated with vitafer or with the butanolic fraction of the extract. The same correction was also observed with the crude root extract of this root (Tchogou et al., 2016). However, it was slower than that of the ethyl acetate fraction (which isolates mainly flavonoids) from the same root for which the correction of the hemoglobin level already occurred on D7 (Sènou et al., 2017). The correction of the hemoglobin level was equivalent to that observed with extracts from the leaf sheath of Sorghum bicolor which is also an anti-anemic plant (Ogwumike, 2002; Godwin et al., 2014).

As hemoglobin was contained in red blood cells, their count was also performed. Their number had significantly decreased on D2 following the hemolysis induced by phenylhydrazine. This decrease was corrected on D10 in the group treated with vitafer and on D15 in the groups treated with the butanolic fraction of Cocos nucifera extract at $40 \mathrm{or} 60 \mathrm{mg}$ / Kg of body weight. This correction was less rapid than those observed with the crude root extract or its ethyl acetate fraction (Tchogou et al., 2016; Sènou et al., 2017). A similar increase in the number of red blood cells had been obtained with crude extracts of the leaves of Tectona grandis (Diallo et al., 2008), of Justicia secunda Vahl (Gbenou et al., 2006) and the bark of Mangifera indica L (Nwinuka et al, 2008) which were also anti-anemic plants.

The mean red blood cell volume increased with a peak on D7 reflecting an early release of macrocytes, immature red blood cells following stimulation of hematopoiesis in the anemic groups. The same observation was made with the crude extract or with the ethyl acetate fraction of the extract (Tchogou et al., 2016; Sènou et al., 2017). A similar observation was also made with the aqueous extract of Hibiscus sabdariffa calyces, which also had antianemic properties (Sènou et al., 2016a).

Unlike the corpuscular volume, the mean corpuscular hemoglobin concentration first significantly increased on D2 corresponding to the presence of red blood cells highly saturated with hemoglobin after hemolysis of phenylhydrazine. It then experienced a fall with a peak at D7, reflecting a release into the blood of hypochromic red cells consistent with macrocytosis to compensate for the anemia. This finding was in agreement with the observations of the crude extract and those of its ethyl acetate fraction (Tchogou et al., 2016; Sènou et al., 2017).

In order to confirm that the released hypochromic macrocytes were indeed young cells, the osmotic resistance of the red blood cells was also determined (Sénou et al., 2016b). In all the anemic groups, the osmotic resistance of the red blood cells had considerably increased from D2 with a peak at D7 reflecting massive release of young red blood cells. Only in the vitafer group, osmotic resistance returned to normal at the end of the experiment indicating release of mature red blood cells. These observations confirmed that the effect of the butanol fraction was less rapid than those of the crude extract or of the ethyl acetate fraction for which there was release of well-differentiated mature red blood cells at the end of the 
experimental period. (Tchogou et al., 2016; Sènou et al., 2017). It was also slower than that of the leaf sheath of Sorghum bicolor (Sènou et al., 2016b).

In order to explore the specificity of action of Cocos nucifera root extract butanolic fraction on erythropoiesis, the number of thrombocytes was also evaluated. The change in the number of blood platelets did not vary between the different groups except for the group treated with $60 \mathrm{mg} / \mathrm{kg}$ of extract fraction where their number was still significantly high on D15 compared to D0. This indicated that this dose stimulated thrombogenesis somewhat, which contrasted with the observations of the crude extract or its ethyl acetate fraction which stimulated the erythrocytic line without activating the thrombocyte line (Tchogou et al., 2016 ; Sènou et al., 2017).

Given that butanol predominantly isolated anthocyanins (Manjusha et al., 2013; Koudoro et al., 2014), hematopoietic activity was probably linked to certain members of this family of compounds. Indeed, some of these compounds had protective effects on the bone marrow and promote hematopoiesis (Choi et al., 2007).

\section{Conclusion}

The butanol fraction of the aqueous root extract of Cocos nucifera stimulated erythropoiesis and hemoglobin synthesis like the crude extract. The effect was not clearly dose-dependent as was the case with the crude extract or its ethyl acetate fraction. The effect was also not specific to erythropoiesis as it also appeared to stimulate thrombopoiesis. Since butanol largely isolates anthocyanins, the observed effect could be attributed to this family of chemical compounds, some members of which promote the function of the hematopoietic bone marrow. However, the study deserves to be continued on the possible synergy of action with other groups of bioactive compounds.

\section{References}

Agbor, G. A., Oben, J. E., \& Ngogang J. Y. (2005). Haematinic activity of Hibiscus cannabinus. AJB, 4(8), 833-837.

Aragão, W. M. (2002). Côco: pós-colheita. Série frutas do Brasil. Brasília: Embrapa Informac ão Tecnológica. http://livraria.sct.embrapa.br/liv_resumos/pdf/00070000.pdf

Bayengue, B. S. S., Ndomou, M., Mogtomo, K. L. M., Ngane, N. A. R., \& Tchiegang, C. (2017). Ethnobotanical survey of medicinal plants used for treating preschool children anemia in an urban setting Douala-Cameroon. AJPS, 11(5), 160-167. https://doi.org/10.5897/AJPS2017.1525

Choi, E. H., Ok, H. E., Yoon, Y., Magnuson Bernadene, A., Kim, M. K., \& Chun, H. S. (2007). Protective effect of anthocyanin-rich extract from bilberry (Vaccinium myrtillus L.) against myelotoxicity induced by 5-fluorouracil. BioFactors, 29, 55-65.

Diallo, A., Gbeassor, M., Vovor A., Eklu-Gadegbeku, K., Aklikokou, K., Agbonon, A. (2008). Effect of Tectona grandis on phenylhydrazine induced anemia in rats. Fitoterapia, 79, 332-6. http://dx.doi.org/10.1016/j.fitote.2008.02.005

Ganong, W. F. (2001). Physiologie Médicale (1st ed.) de l'Université Broeck. 828p.

Gbéassor, M. Y., Kossou K., Amegbo, K. A., \& Koumaglo, D. (1989). Antimalarial effects of eight African medicinal plants. Journal of Ethnopharmacology, 25, 115-118. https://doi.org/10.1016/0378-8741(89)90051-2

Gbenou, J. D., Tossou, R., Dansou, P., Fossou, M., \& Moudachirou, M. (2006). Etude des propriétés antianémiques de Justicia secunda Vahl (acanthaceae) chez les rats de souche wistar. Pharm Med Trad Afr, 14, 45-54.

Godwin, I., Ayuba, G., Jensen, G., Benson, K., Okubena, A., \& Okubena, O. (2014). Clinical efficacy of a West African Sorghum bicolor-based traditional herbal preparation Jobelyn Shows. Increased Hemoglobin and CD4+ T-Lymphocyte Counts in HIVPositive Patients. Journal of alternative and complementary medicine, 20(1), 53-56. http://dx.doi.org/10.1089/acm.2013.0125

Koudoro, Y. A., Dedomè, L. S. O., Yovo, M., Agbangnan-Dossa, C. P., Tchobo, P. F., Alitonou, G. A., Avlessi, F., \& Sohounhloué, D. C. K. (2014). Chemical characterization, antiradical and antibacterial activities of extracts of the root bark of Cochlospermum planchoni of Benin. International Journal of Innovation and Applied Studies, 7(4), 1582-1594.

Manjusha, S., Abrar Hussain, M., Manik, S., Mohhd, Y. M., Sumeerah, Q., Mohd, I. M., \& Yogesh, C. (2013). Phytochemical Screening and in-vitro Antioxidant Activity Isolated Bioactive Compounds from Tridax procumbens Linn. Pakistan Journal of Biological Sciences, 16(24), 1971-1977. https://doi.org/10.3923/pjbs.2013.1971.1977

Nwinuka, N. M., Monanu, M. O. \& Nwiloh, B. I. (2008). Effect of Aqueous Extract of Mangifera indica L (Mango) Stem Bark on Haematological Parameters of Normal Albino Rats. Pak J. of $\mathrm{Nu}$, 7, 663-6. http://dx.doi.org/10.3923/pjn.2008.663.666

Ogwumike, O. O. (2002). Hemopoietic effect of aqueous extract of the leaf sheath of Sorghum bicolor in albinos rats. 
African Journal of Biomedical Research, 5, 69-71.

Sènou, M., Agossadou, A., Agbangnan, D. C. P., Tchogou, A. P., Assogba, F., Klotoé, J. R., ... Loko, F. (2016a). The Aqueous Extract of Hibiscus sabdariffa L calyces effectively Corrects induced anemia. IJPPR, 7(4), 254-265.

Sènou, M., Tchogou, A. P., Agbangnan, D. C. P., Dougnon, T. V., Ogué, P., Agossadou, A., ... Sèzan, A. (2017). Efficacy of ethyl acetate fraction of Cocos nucifera aqueous extract on the treatment of anemia. International Journal of Pharmaceutical Science Invention, 6(9), 44-51.

Sènou, M., Tchogou, A. P., Dougnon, T. V., Agossadou, A., Assogba, F., Kinsiclounon, E. G., ... Loko, F. (2016b). Efficiency of Sorghum bicolor extract in the treatment of induced anemia on Wistar rats. International Journal of Biosciences, 8(4), 62-71. http://dx.doi.org/10.12692/ijb/8.4.62-71

Sofowora, A. (1996). Plantes médicinales et médecine traditionnelle d'Afrique. Edition Karthala, 75013 Paris, pp: 375.

Tchogou, A. P., Sènou, M., Agbangnan, D. C. P., Agossadou, A., Assogba, F., Dougnon, T. V., ... Loko, F. (2017). Test of the safety of Cocos nucifera L. (Arecaceae) root aqueous extract. Journal of Chemical. Biological and Physical Sciences, 7(1), 282-291. https://doi.org/10.5539/ijb.v8n3p1

Tchogou, A. P., Sènou, M., Dougnon, T. V., Agossadou, A., Assogba, F., Kinsiclounon, E. G., ... Loko, F. (2016). The Aqueous Extract of Cocos nucifera L. (Arecaceae) effectively treat induced anemia. Experimental Study on Wistar Rats. International Journal of Biology, 8(3), 1-9. https://doi.org/10.5539/ijb.v8n3p1

UNICEF. (2015). Levels \& Trends in Child Mortality. Report of a scientific group of UNICEF, 6.

UNICEF. (2017). Levels \& Trends in Child Mortality. Report of a scientific group of UNICEF, 36.

Upasana, S., Purva, S. D., Susmita, S., Vishaharini, V., \& Madhu, M. (2018). Plant extracts as an astounding remedy to anemia. Annals of Plant Sciences, 7(4), 2166-2171. https://doi.org/10.21746/aps.2018.7.4.16

\section{Copyrights}

Copyright for this article is retained by the author(s), with first publication rights granted to the journal.

This is an open-access article distributed under the terms and conditions of the Creative Commons Attribution license (http://creativecommons.org/licenses/by/4.0/). 